\title{
Consuming Life after Anti-Trafficking
}

Sofie Henriksen

\begin{abstract}
The rise of transnational, market-based anti-trafficking organisations has expanded the anti-trafficking domain to include Western corporations and consumers. In an effort to improve living conditions for survivors of trafficking, these organisations sell commodities produced by former victims or women at risk of human trafficking and brand them as symbols of a new and better life after anti-trafficking. Thus, life after antitrafficking is not isolated to the locations of the trafficking victims, but occurs in distant areas and among diverse groups of people. This article investigates how representations of life after anti-trafficking engage consumers, corporations and NGO workers in New York City through the sale and purchase of 'slave-free' products made by Southeast Asian women deemed 'survivors of trafficking'. The ethnographic data illustrates how life after anti-trafficking unfolds in the context of US corporate and consumer culture and intersects with capitalist discourses of freedom, consumer ethics and politics of market-based aid. Consequently, life after antitrafficking creates new consumer identities, anti-trafficking aid strategies and business opportunities detached from the actual victims of human trafficking.
\end{abstract}

Keywords: life after anti-trafficking, market-based anti-trafficking, United States, ethical consumption, slavery, sex work

Please cite this article as: S Henriksen, 'Consuming Life after Anti-Trafficking', Anti-Trafficking Review, issue 10, 2018, pp. 14-33, www.antitraffickingreview.org

\section{Introduction}

'Are you familiar with Kanwi Community?'1 asked Carrie, my 22-year-old co-worker, to a potential customer who had approached the small booth where we were selling colourful purses, tote bags, t-shirts and jewellery in a corner of the annual Christmas market at Union Square in Manhattan. The middle-aged woman, who had stopped to look at the display of Christmas ornaments, was not. 'We are a non-profit which creates economic opportunities for survivors or women at risk of human trafficking. These were handmade by women in Cambodia who have been rescued from human trafficking,' Carrie explained, smiling and pointing to the ornaments. 'The profits from the sales go directly back to them.' The woman, carrying shopping bags in her hands, took a look around the booth and replied 'oh wow, that's great'. After looking at different items she decided to purchase a couple of Christmas ornaments and three colourful bracelets. The bracelets, she told us, were for her niece. 'Do you have something with the story on it?' she asked. 'I need something to tie it to the cause. She is really into causes. ${ }^{2}$

The woman in the field note excerpt was not the only consumer at the market requesting a concrete connection between her purchase and the cause of human trafficking. In fact, she exemplifies a broader trend: the fight against trafficking has emerged as a new consumer interest that includes Western consumers in the diverse and expanding group of anti-trafficking stakeholders. The growing tendency of global anti-trafficking initiatives to rely on consumers and corporations to support women who have been 'rescued'3 from human trafficking highlights how life after anti-trafficking emerges and unfolds in sites far away from the people considered victims of trafficking. Thus, by selling and purchasing handbags and t-shirts, NGO workers and consumers shape and participate in life after anti-trafficking. The excerpt also illustrates how market and consumer-based anti-trafficking efforts intersect with a larger contemporary consumer movement committed to consuming for a

Name of the organisation has been changed.

Field notes, 18 November 2016.

I placed rescued in quotation marks to indicate my awareness of the various and critical perspectives on trafficking and anti-trafficking efforts which complicate the notion of rescue. Hereafter, I will not use quotation marks. 
cause ${ }^{4}$ often referred to as ethical consumption. At this intersection, representations of life after anti-trafficking become causes through which consumers can identify as being ethical.

But what makes consumers engage in life after anti-trafficking? And how does life after anti-trafficking emerge as a business opportunity for corporations and people otherwise unrelated to the cause of human trafficking? This article uses ethnographic data collected among sellers and buyers of anti-trafficking commodities in New York City to elucidate how life after anti-trafficking forms and takes place in the growing sector of marketbased anti-trafficking NGOs. By analysing the practices and perceptions of life after anti-trafficking in this setting, the article shows how the turn to a market-based anti-trafficking strategy creates business opportunities beyond the actual location of the trafficking victims, ethical consumer identities and a new form of antitrafficking work that combines aid and trade, both in practice and discourse.

\section{Life after Anti-Trafficking}

Both contemporary and early struggles against human trafficking have commonly been understood as humanitarian causes striving to save exceptional lives. ${ }^{5}$ In the US, a diverse coalition, termed 'new abolitionists', has been dominant in defining trafficking largely as an issue of female sexual slavery. ${ }^{6}$ The common ground for these new abolitionists, which include left-wing feminists and evangelical Christians, is an anti-prostitution stance that combines religious condemnation of sex outside of marriage and feminist arguments that commercial sex is always a form of patriarchal violence against women. ${ }^{7}$ The linkages of religious conservative sexual morals and a feminist language of female victimhood were influential in the formulation of a political anti-trafficking framework in 2000 and the political efforts following, which have been called 'a moral crusade against prostitution'. ${ }^{8}$ Thus, anti-trafficking policies have placed particular emphasis on trafficking into sexual labour and singled it out as a particularly severe form of suffering compared to other forms of labour exploitation. This focus has enlivened moral panics about female sexuality and imbued the issue of trafficking with a sense of urgency that requires immediate (and even militarised) ${ }^{9}$ humanitarian action. Consequently, US anti-trafficking efforts have largely focused on police operations to raid sex industry sites and rescue the women there. ${ }^{10}$

However, scholars of trafficking, sex work and migration have emphasised the importance of looking beyond moral panics and the urge to rescue women, and document the long-term realities of life after trafficking. ${ }^{11}$ Some of these realities have been revealed through ethnographic studies of NGOs working within what sociologist Elena Shih has critically termed the anti-trafficking rehabilitation complex. ${ }^{12}$ This term refers to the growing number of NGOs with a 'rehabilitation through labour' approach to anti-trafficking, in which vocational training, low-wage employment and commodity production for a Western consumer market is deployed as a 'victim repair' strategy for rescued female sex workers. Shih's work shows that despite allegedly being rescued from 'sex slavery', many women found working conditions at the NGOs oppressive and did not experience the purported freedom that anti-trafficking organisations proclaimed to provide. Shih argues that

4 L A Richey and S Ponte, Brand Aid: Shopping well to save the world, University of Minnesota Press, Minnesota, 2011.

5 M Ticktin, Casualties of Care: Immigration and the politics of humanitarianism in France, University of California Press, Berkeley \& Los Angeles, 2011, pp. 18, 170; on exceptionalism and exclusion in trafficking law and representations, see: W Chapkis, 'Trafficking, Migration, and the Law', Gender \& Society, vol. 17, issue 6, 2003, pp. 923-937; E O’Brien, 'Ideal Victims in Trafficking Awareness Campaigns' in K Carrington, M Ball, E O'Brien and J Tauri (eds.), Crime, Justice and Social Democracy: International perspectives, Palgrave Macmillan, Basingstoke, 2013, pp. 315-325.

6 E Bernstein, 'The Sexual Politics of the "New Abolitionism"”, Differences: A Journal of Feminist Cultural Studies, vol. 18, issue 3, 2007, pp. 128-151.

7 A W Peters, "Things that Involve Sex are Just Different": US anti-trafficking law and policy on the books, in their minds, and in action', Anthropological Quarterly, vol. 86, issue 1, 2013, pp. 230-1.

$8 \quad$ R Weitzer, 'The Social Construction of Sex Trafficking: Ideology and institutionalization of a moral crusade', Politics \& Society, vol. 35, no. 3, 2007, pp. 447-475.

9 E Bernstein, 'Militarized Humanitarianism Meets Carceral Feminism: The politics of sex, rights, and freedom in contemporary antitrafficking campaigns', Signs, vol. 36, no. 1, 2010, pp. 45-71.

10 G Soderlund, 'Running from the Rescuers: New US crusades against sex trafficking and the rhetoric of abolition', NWS A Journal, vol. 17, issue 3, 2005, pp. 64-87.

11 S Plambech, "Between "Victims" and "Criminals": Rescue, deportation, and everyday violence among Nigerian migrants', Social Politics, vol. 21, 2014; D Brennan, 'Life Beyond Trafficking', Contexts, vol. 13, 2014.

12 E Shih, 'The Anti-Trafficking Rehabilitation Complex', Contexts, vol. 13, 2014. 
rather than increasing the long-term economic prospects of sex workers, the rehabilitation programmes and their representations of life after anti-trafficking only generate income for NGOs. This argument is echoed by Claudia Cojocaru's concept of secondary exploitation, which emphasises how misleading representations of sex workers and trafficking victims are 'repackaged for consumption' by various actors. ${ }^{13}$ Following these insights, I argue in this paper that life after anti-trafficking exists both as a lived experience for rescued victims of trafficking — actual or labelled — and as a specific but possibly very different representation of a new, successful and empowered life path, which adds value to the commodities produced. In this way, the representation of life after anti-trafficking becomes a consumable product itself. It is this representation, sold by market-based antitrafficking organisations to Western consumers, I refer to and examine in this article as life after antitrafficking. I use the term life after anti-trafficking rather than life after trafficking to emphasise how the representation frames the anti-trafficking programme as having an essential role in shaping victims' new and successful life ventures. As I will illustrate, this framing is crucial to the success of the representation as a commodity.

\section{Shopping for a Better World}

The representation of life after anti-trafficking has travelled remarkably well and increasingly been integrated into contemporary trends of ethical consumption and cause-related marketing. Although expressing social and political values through consumption dates back to campaigns to boycott slave-grown sugar in the early nineteenth century, ${ }^{14}$ the market for specifically labelled 'ethical' commodities has spiked in recent decades with the development and popularity of certifications such as Fairtrade, which is branded as a sustainable alternative to conventional trade systems. ${ }^{15}$ Consumption of Fairtrade labelled goods that guarantee fair production conditions relies on the idea that fairer trading relations will increase the niceness of global capitalism and alleviate the harmful effects of traditional consumption. ${ }^{16}$ However, consumption is increasingly applied as a solution to issues unrelated to consumption, exemplified by cases of cause-related marketing, in which portions of the sales profit from shoes goes to alleviate poverty, or profits from iPods are used to fight HIV and AIDS. Thus, consumers are offered the chance to engage in humanitarian causes through shopping, or what has been termed 'shopping for a better world'. ${ }^{17}$ Scholars claim that this development correlates with a recent shift from conscious consumption to compassionate consumption, which relies less on information and labels and more on celebrity mediation and emotional appeals. ${ }^{18}$ Thus, the category of ethical consumption has grown to incorporate various meanings, aims and moralities of 'doing good', in effect making everyday consumption practices an arena for forming and displaying 'moral selves'19 or engaging in what has critically been termed 'low-cost heroism'. ${ }^{20}$ That is, ethical consumption in this form allows consumers to perform moral, heroic acts simply by continuing their everyday consumption patterns. However, as I discuss below, compassionate and ethical consumption presents considerable dilemmas and ambiguities for consumers to navigate.

\section{The Politics of Market-based Anti-Trafficking}

As the introductory excerpt illustrates, human trafficking has been added to the line of causes that engage compassionate Western consumers. Through market-based anti-trafficking campaigns, they are offered the chance to 'fight human trafficking' by purchasing goods produced by former victims of trafficking in non-

13 C Cojocaru, 'My Experience is Mine to Tell: Challenging the abolitionist victimhood framework', Anti-Trafficking Review, issue 7, 2016, pp. 12-38. See also: A I Fukushima and J Hua, 'Calling the Consumer Activist, Consuming the Trafficking Subject' in L Cucklanz and H McIntosh (eds.), Documenting Gendered Violence, Bloomsbury Academic \& Professional, 2015, p. 57.

14 A Berlan, 'Good Chocolate? An examination of ethical consumption in cocoa' in J Carrier and P Luetchford (eds.), Ethical Consumption: Social value and economic practice, Berghahn Books, New York \& Oxford, 2012, pp. 43-59.

15 J G Carrier, 'Introduction' in J Carrier and P Luetchford, 2012, p. 2.

16 M K Goodman, 'Reading Fair Trade: Political ecological imaginary and the moral economy of Fair Trade Foods', Political Geography, vol. 23, issue 7, 2004, pp. 891-915.

17 Richey and Ponte, p. 9.

18 Ibid., p. 126.

19 C Dolan, 'Market Affections: Moral encounters with Kenyan Fairtrade Flowers', Ethnos, vol. 72, issue 2, 2007, pp. 239_ 261; L M Vramo, “Trade, not Aid”: Imagining ethical economy' in J Carrier and P Luetchford, 2012, pp. 81-98.

20 Richey and Ponte, p. 82. 
Western countries. The goods offered by the organisations include pyjamas, purses, denim wear, jewellery, tea, and soap branded as 'slave-free'. While the emergence of these so-called Rescue Brands ${ }^{21}$ has spurred academic and public criticism for exploiting human trafficking as a marketing tool, ${ }^{22}$ they have continued to attract consumer support and popularity. Market-based anti-trafficking occupies a space between Fairtrade and compassionate consumption. On the one hand, purchasing anti-trafficking products is marketed as a sustainable and ethical alternative to traditional consumption and thus, similar to the Fairtrade movement; market-based anti-trafficking relies on the idea that consuming in 'nicer' ways will solve the problems caused by global consumption. Market-based anti-trafficking thus treats trafficking as a problem related to capitalist market mechanisms, yet proposes a market solution, which indicates the movement's paradoxical stance as both 'in and against the market'. ${ }^{23}$ On the other hand, market-based anti-trafficking resembles the tendency of compassionate consumption by applying consumption as a solution to trafficking even when the commodities sold have nothing to do with trafficking. That is, instead of improving an existing market exchange, marketbased anti-trafficking seeks to establish new and rather unrelated markets for slave-free soap, jeans and purses. These campaigns do not advocate for the establishment of fair labour and trade conditions for the work people are already doing, but for the rescue and removal of people from sex industries. Thus, they appeal to consumers' sense of compassion rather than fairness.

The inclusion of consumers in the fight against trafficking reflects the contemporary political landscape of antitrafficking, which by the Obama administration was called a whole-of-society-effort requiring law enforcement, NGOs, the private sector and consumers to act. ${ }^{24}$ US anti-trafficking efforts have therefore been expanded to include civil vigilante rescue operations, ${ }^{25}$ Internet surveillance technologies, ${ }^{26}$ corporate partnerships, ${ }^{27}$ and consumer activism. Thus, market-based anti-trafficking emerges in a humanitarian landscape of shifting relationships between state, market and civil society, in which consumers and corporations rather than states become responsible for global aid. ${ }^{28}$ Sociologist Elizabeth Bernstein utilises the concept of global corporate governance to describe the increasingly dominant position of corporate actors in the field of social and humanitarian work through which for-profit interests and social justice goals are merged and market-based aid is justified as a result of a redemptive capitalism..$^{29}$

The flourishing of anti-trafficking consumer movements, which aim to support the new life ventures of trafficking victims, indicates that life after anti-trafficking increasingly unfolds across multiple and disparate domains. In this article, I will discuss how it emerges in the domain of New York consumers.

\section{Methodology and Ethnographic Context}

In the fall of 2016, I worked as a sales intern and conducted four months of ethnographic fieldwork at the antitrafficking organisation Kanwi in New York City. Kanwi was founded by three American women, who decided to work to create economic opportunities for survivors and women at risk of human trafficking, after they had witnessed young women being sold to sexual labour in Cambodia during a school trip. The organisation now operates in two Southeast Asian sites, where they train women who are former victims or at risk of human

21 S Miller, 'Buy These Pajamas \& Rescue a Prostitute; Or, Why Rescue Brands Are Dumb', Jez̧ebel, 2 March 2015, retrieved 26 December 2017, https://jezebel.com/buy-these-pajamas-rescue-a-prostitute-or-why-rescue-1688197906.

22 A E Moore and M Mendes, "Unraveling”: Anti-Trafficking NGOs and the garment industry', TruthOut, 29 August 2014, retrieved 14 April 2016, http://www.truth-out.org/opinion/item/25657-unraveling-anti-trafficking-ngos-andthe-garment-industry; Fukushima and Hua, p. 48.

23 Goodman, pp. 892-3.

24 S Coppedge and A Pope, 'How the Obama Administration Fought Human Trafficking', CNN, 18 January 2017, retrieved 1 December 2017, http://edition.cnn.com/2017/01/18/opinions/human-trafficking-progressobama/index.html.

25 E Shih, Not in My "Backyard Abolitionism": Vigilante rescue against American sex trafficking', Sociological Perspectives, vol. 59, issue 1, 2016, pp. 66-90.

26 J L Musto and D Boyd, 'The Trafficking-Technology Nexus', Social Politics, vol. 21, issue 3, 2014, pp. 461-483.

27 E Bernstein, 'Redemptive Capitalism and Sexual Investability' in A S Orloff, R Ray and E Savci (eds.), Perverse Politics? Feminism, Anti-Imperialism, Multiplicity (Political Power and Social Theory, vol. 30), Emerald Group Publishing Ltd., 2016, pp. 45-80.

28 Dolan, p. 240-1.

29 Bernstein, 'Redemptive Capitalism'. 
trafficking to manufacture products. ${ }^{30}$ The training includes what they call 'life skills' such as reading, writing, math, financial planning, and emotional and mental health development facilitated by social workers and art therapists. Additionally, the work in Southeast Asia consists of training local NGOs with production facilities to employ more women who are victims or at risk of trafficking. Kanwi's headquarters are located on the $12^{\text {th }}$ floor of a building in an affluent area of Manhattan. The organisation has a wide reach with a number of interns and volunteers, in addition to eight full-time staff members, a board of directors, a board of advisors, a young professionals board and a number of celebrity ambassadors. In the US, Kanwi sells the products made by the women in their programmes at markets, fairs and online. Their work in the US is aimed at engaging retailers and consumers in the anti-trafficking movement by advocating for slave-free consumption and clean supply chains. ${ }^{31}$ I collected data at Kanwi's office in New York, where I participated in various sales events, staff meetings, conferences, and volunteer trainings. I also conducted interviews with employees and consumers of Kanwi. By being included in the staff team but simultaneously questioning and sharing my reflections on their work approach, I was positioned as both a participant and critical observer. On several occasions, I shared my critical thoughts with employees on aspects of their work, both in order to hear their responses, and also to reciprocate the trust and sincerity I was experiencing from them. I have pseudonymised the organisation to permit a discussion of these critical reflections without jeopardising the organisation's future financing opportunities.

Overall, Kanwi seeks to provide women with production skills and market access and create a specific US consumer demand in order to end trafficking. The approach relies on the assumption that if women are equipped with skills to produce, and if consumers demand their products, the women will be at less risk of having to do sexual labour and thus become victims of trafficking. Thus, in the genealogy of anti-trafficking, Kanwi represents a 'traditional' abolitionist movement with its emphasis on the harms of commercial sex, but also takes a contemporary whole-of-society-approach and emphasis on production and labour rights inspired by ethical trade movements, such as the anti-sweatshop movement. Kanwi bridges their engagement in these distinct movements by branding their products as slave-free-a rhetoric used in both movements through the term 'modern day slavery'.

However, despite their reliance on production labour and consumer awareness as an effective anti-trafficking solution, only 13 per cent of the organisation's total income in 2016 came from sales of anti-trafficking commodities. Most funding came from more traditional sources such as individual and corporate donations. Yet, as I will show in the following section, an important part of Kanwi's work consisted precisely of distinguishing themselves from traditional humanitarian aid.

30 When asked what qualified as 'at risk', the co-founder explained that Kanwi define certain local areas as at risk and thus every woman who lives in that area is deemed at risk.

31 In the case of Kanwi's anti-trafficking work, clean supply chains describe business operations in which no level of supply relies on or involves labour exploitation or forced labour. 


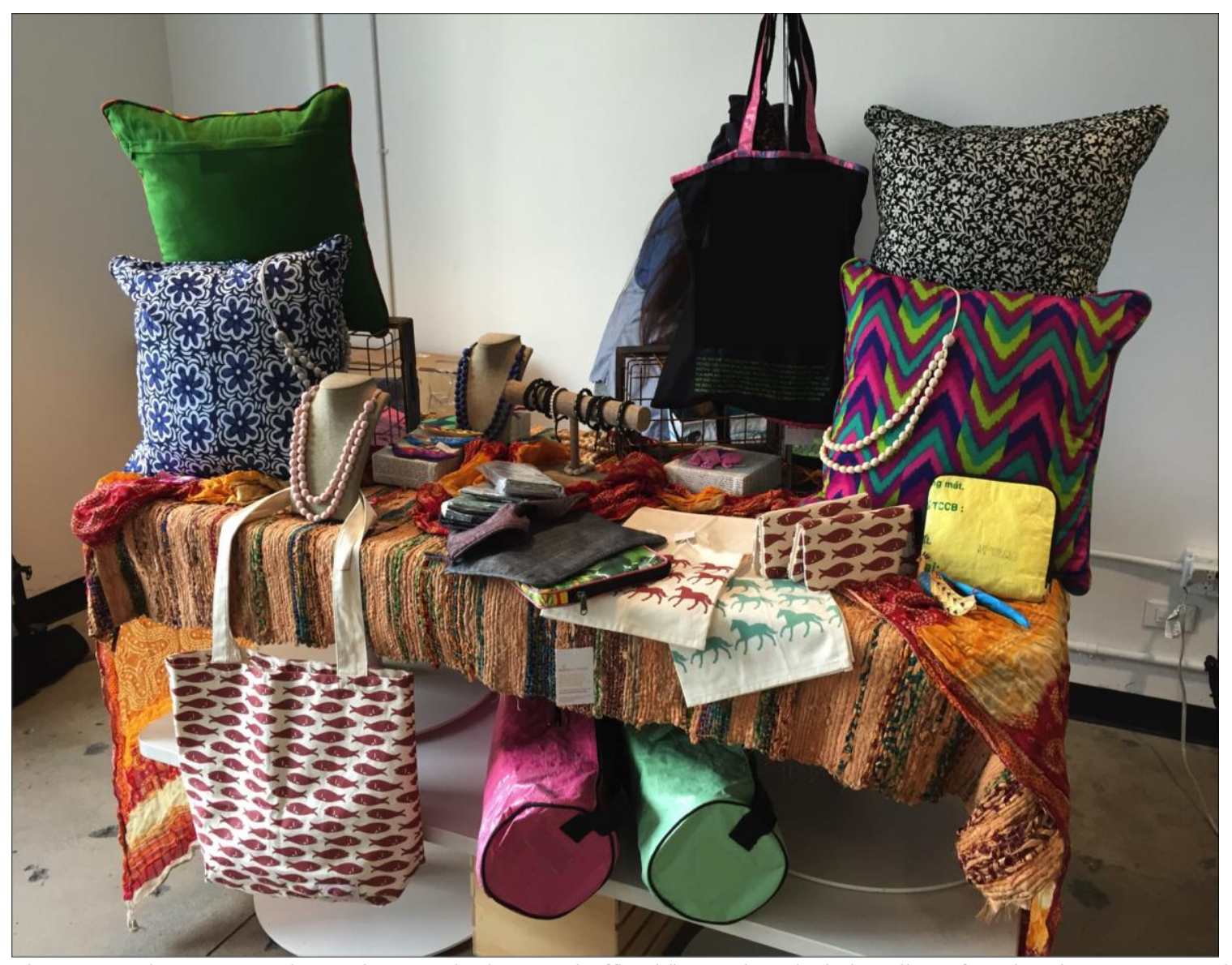

Figure 1: Products presented at a sales event in the Kanwi office. The products include wallets of varying sizes, patterns and colours, handbags, clutch purses, laptop cases, necklaces, bracelets, tote bags, t-shirts, scarves, ornaments and ties. The prices range from USD 8 for bracelets to USD 78 for bags. A team in New York, consisting of professional designers and warehouse representatives, designs the products and reviews samples before items are approved for production.

\section{From Rescue to Rehabilitation}

In many ways, Kanwi resembles traditional anti-trafficking approaches with their use of victim narratives featuring young women and girls tricked or forced into sex work by male traffickers. These narratives follow 'true victimhood scripts' as defined by discourses of sexual humanitarianism, ${ }^{32}$ emphasising individual, exceptional and gendered suffering. However, in presentations of their work, Kanwi also emphasises poverty and global economic structures, rather than merely 'evil men', as the primary drivers of trafficking. Therefore, their target is to secure a stable and independent income for the women in their lives after trafficking. Employees at Kanwi would often state that Kanwi does not do 'the rescuing' but is there 'in the aftermath' to rehabilitate. They considered this focus on life after trafficking a sustainable alternative to traditional humanitarian aid and a response to the criticism of anti-trafficking organisations that focus merely on the rescue of victims and not on creating sustainable livelihoods for the women afterwards. ${ }^{33}$ A young employee, Carrie, who had been working with Kanwi as a volunteer in college and was now a full-time sales manager, explained that: Kanwi creates a market place and job-creation.... It is not necessarily a hand-out, not creating this dependent kind of relationship where the women are just given things.... What Kanwi does is very much empowerment in that these women are given opportunities and then they take those opportunities and they expand them on their own.'

32 N Mai, 'Embodied Cosmopolitanisms: The subjective mobility of migrants working in the global sex industry', Gender, Place and Culture, vol. 20, issue 1, 2013, pp. 107-124.

33 See, for example: C Vance, 'Melodramatic Narratives of Sex Trafficking and their Consequences for Law and Policy', History of the Present, vol. 2, no. 2, 2012, p. 211. 
Carrie's quote illustrates a variant of what anthropologists have identified as a traditional Western belief in the capitalist market as liberating by the transformational force of money. ${ }^{34}$ Empowerment in Kanwi's work is equated with having access to a commodity market. ${ }^{35}$ Furthermore, the opposition against hand-outs expressed by Carrie draws parallels to development approaches under the slogan 'Trade Not Aid', first coined at the UN Conference on Trade and Development in 1964. The slogan was used to argue for better trade conditions for developing countries instead of humanitarian aid. In line with this slogan, development initiatives reliant on 'giving' have been perceived to create social obligations and dependencies in contrast to initiatives focusing on trade relations, which is assumed to bring about individual and lasting development. ${ }^{36}$ This perception has long been articulated as the development cliché of 'teaching a man to fish' as opposed to feeding him fish ${ }^{37}$ providing people the production tools to engage in trade relations is considered more valuable than simply providing aid.

The anti-trafficking work of Kanwi aligns to this idea in their focus on providing the women with production skills to enter a market and thereby secure a livelihood by producing consumer goods. Kanwi subscribes to economic development discourses and the idea that a successful and empowered life after trafficking cannot rely on aid, but must include the entrance into a formal capitalist economy of commodity production. Their approach illustrates a shift from rescue to rehabilitation, or in other words, a shift from humanitarian responses to market-based development strategies focused on production skills. The women in the Kanwi programmes are employed by local NGOs that Kanwi collaborates with and from whom it purchases products. According to an employee at Kanwi, the women are paid four times more per hour than the minimum wage in the local areas, although this is not confirmed in any of the organisation's reports. Profits from sales in the US are reinvested in the programmes to continue and expand the efforts to provide women with production skills. However, as anthropologist James Ferguson points out, this 'productionist' approach relies on the assumption that there is a demand for the skills that are taught. ${ }^{38}$ But do we really need more trained female garment workers? Are the women in Kanwi's programmes secured of a long-term income and economic empowerment simply by having production skills? Creating more trained workers seems counterproductive in a contemporary global economy, which according to Ferguson, is challenged by a massive oversupply of labour that cannot be absorbed by production industries.

Based on this reflection, I asked different members of the Kanwi staff what happened to the women who were not hired by NGOs after completing their training programmes or if the NGOs did not receive enough product orders to employ the women anymore. I was hoping to obtain a deeper understanding than what I had learned from the statistics and success stories from Kanwi's reports. How many livelihoods are sustained by the product sales? What happens if people stop buying the products? Can the women use their skills in other jobs? The responses I received were aligned strictly to the official statements. The co-founder, Erin, explained that the women either started up their own businesses or were hired to train other women in the programmes. These responses could reflect either that the employees in New York did not know exactly what happened to the women or that they did not want to share specific details, which is neither unlikely nor unreasonable given the fear of bad publicity from journalists or researchers experienced by organisations that rely on public funding. This fear required me to continuously balance my critical inquiries to sustain my access to and the trust of my interlocutors.

34 M Bloch and M J Parry, Money and the Morality of Exchange, Cambridge University Press, New York, 1989.

35 For a critical discussion of the presentation of 'female empowerment' as a depoliticised economic issue in contemporary development discourse, see: K Cronin-Furman, N Gowrinathan and R Zakaria, Emissaries of Empowerment, The Colin Powell School for Civic and Global Leadership, 2017. For a similar critique written by female sex workers, see: Empower Foundation, Hit \& Run: The impact of anti-trafficking policy and practice on sex worker's buman rights in Thailand, Empower Foundation, Chiang Mai, 2012, chapter 5.

36 R L Stirrat and H Henkel, 'The Development Gift: The problem of reciprocity in the NGO world', The Annals of the American Academy of Political and Social Science, vol. 554, 1997, p. 73.

37 The slogan reads: 'Give a man a fish, and you feed him for a day. Teach a man to fish, and you feed him for a lifetime.' J Ferguson, 'Give a Man a Fish: From patriarchal productionism to the revalorization of distribution' in J Ferguson, Give a Man A Fish, Duke University Press, Durham, 2015.

38 Ibid., p. 36. 
Despite framing their approach as economically sustainable, a large part of Kanwi's efforts consisted of actively creating a corporate and consumer demand for the commodities. Thus, as I will discuss in the next section, the rehabilitation strategy of Kanwi required market-oriented anti-trafficking work.

\section{Making the Anti-Trafficking Business Case}

Kanwi sought to create a corporate demand of the anti-trafficking commodities by establishing partnerships with social media celebrities and multinational retailers. At team meetings, Kanwi employees discussed marketing strategies based on how to 'drive traffic' to their social media pages to 'hit the right trends' and to be mentioned by the right bloggers. Furthermore, this strategy included reaching out to corporations to get them involved in Kanwi's work. For this purpose, Erin, the co-founder of Kanwi, and I attended a conference at New York University, at which I assisted her in hosting a discussion workshop focusing on how to 'make the business case' for anti-trafficking commodities. The participants discussed ways to convince businesses that clean supply chains and slave-free production was not only the right thing to do, but also a way to make profit. The theme of the discussion aligned with the notion of a redemptive capitalism—a capitalism that is good for all. ${ }^{39}$ However, rather than capitalism conforming to humanitarian ideals, the participants of the workshop argued it had to be the other way around. Kelly, a young fashion designer, argued that in order to persuade businesses to join the fight against trafficking, the quality of the products had to improve. She stressed the importance of building a quality brand able to 'compete on regular market terms' since the market for ethical products with a unique and heart-warming story behind it had become too saturated. Thus, even non-profit anti-trafficking NGOs are required to compete on market terms and must appeal to businesses not in terms of the humanitarian reasons to engage in anti-trafficking work but in terms of the market value of such work. In this way, market logic is used to justify anti-trafficking as a business opportunity.

The economic justification is also found in Kanwi's language of investments. Kanwi's promotional material features an encouragement to 'invest in her', and Carrie explained to me that Kanwi's work was about 'investing in people'. This reflection mirrors a growing language of investing in social problems, ${ }^{40}$ but demonstrates an interesting contrast in the case of anti-trafficking-between investing in her and buying her. Since trafficking is commonly recognised as the commodification, buying and selling of people, ${ }^{41}$ arguing for the turn to a capitalist market for solutions might seem conflicting. However, the use of a language of investments points to specific moral distinctions within practices and logics of trade. Trade is considered morally bad if it consists of buying bodies, but morally good if it means investing in people. As an economic concept, investing refers to the purchase of goods that are not consumed immediately but will create wealth and profit in the future. Thus, investments are at the core of capitalism as they are directed towards a continuous accumulation of profit rather than the consumption of objects for their use-value..$^{42}$ In this sense, the term might provoke stereotypical images of Wall Street capital investors not usually associated with altruistic or humanitarian motives. However, in the case of Kanwi, a language of investments is invoked as a morally good opposition to the immoral trade in bodies in cases of human trafficking. Michelle Murphy, a Professor of Women Studies, argues that the idea of investing in women as a key to eradicating poverty rests on the framing of human productivity and abilities to produce profits as buman capital, famously conceptualised by neoliberal economists in the 1960s. It has been argued by economists that investing in women and girls (i.e. their education and health resources) yields the highest rate of return of all possible investments in the developing world. ${ }^{43}$ Thus, when speaking of investing in rather than buying people, the idea of viewing people as sources of capital is morally legitimised. Through this moral distinction between good and bad trade, Kanwi was able to legitimately position anti-trafficking in cost/benefit calculations and make the business case for anti-trafficking as a good investment. The approach of Kanwi thus relies on the argument that anti-trafficking work can create

39 Also articulated as 'just capitalism', see Richey and Ponte, p. 11.

40 L King and E Gish King, 'Marketizing Social Change: Social shareholder activism and responsible investing', Sociological Perspectives, vol. 58, no. 4, 2015, pp. 711-730.

41 See, for example: http://www.traffick911.com/what-is-trafficking/. Similarly, trafficking is commonly referred to as the illicit trade in people: 'UNODC on Human Trafficking and Migrant Smuggling', United Nations Office on Drugs and Crime, retrieved 29 June 2017, https:/ / www.unodc.org/unodc/human-trafficking/.

42 L Boltanski and E Chiapello, The New Spirit of Capitalism, Verso Books, 2005, pp. 5-6.

43 M Murphy, 'The Girl: Mergers of feminism and finance in neoliberal times', Gender, Justice, and Neoliberal Transformations, Special issue of the Scholar and Feminist Online, 2013. 
positive outcomes for not only the rescued victim but also businesses and investors. By emphasising the mutual benefits of abolishing trafficking, Kanwi further distinguishes their approach from gift-like aid work, since it is framed as involving equal, independent and mutually benefitting actors. This framing shows how the representation of life after anti-trafficking is built upon and sold through normative ideas of economic independence as empowerment and freedom.

These examples show how life after anti-trafficking unfolds in a corporate setting, creating new ways of doing anti-trafficking work that follow corporate structures. Thus, the conditions for the actual life after antitrafficking are largely created in locations and situations completely detached from the people living in situations defined as such. This raises questions for the purported independence and individual empowerment provided by this type of anti-trafficking work. The idea of economic independence is further challenged by the need for a constant consumer demand which, as I will discuss in the following section, depends on the conversion of unethical to ethical consumers.

\section{Creating the Anti-Trafficking Consumer}

A large part of my time with Kanwi was spent attending sales events in which I and one or two other employees sold anti-trafficking commodities. The sales events ranged from a 'taco night' at a Long Island restaurant to a champagne cruise on a 168-foot luxury yacht, where Kanwi sold goods while cruising the Hudson River. Between these events were art shows, street parties, fashion shows, church fairs, Christmas markets, a lunch event at The $5^{\text {th }}$ Avenue Plaza Hotel and private 'bag parties' hosted by consumers or employees. Thus, the group of people purchasing Kanwi products was diverse in many aspects, yet most were white or Asian-American women in their 20s or 30s. Most of the consumers described themselves as socially conscious, although few were specifically interested in human trafficking. How, then, did anti-trafficking emerge as a consumer interest for these people?

Among the Kanwi employees, and even among consumers themselves, it was widely assumed that consumers were generally self-centred and driven by economic rationality. Since 'ethical' bags and t-shirts are more expensive than similar items from common department stores like H\&M, shopping ethically requires a rejection of the rationality assumed to be inherent in consumption, or what one consumer, Irene, called 'the capitalist ethos' of the US consumer culture: 'I mean we are a calculus society you know... whether one is ethical or not you will buy the cheaper one even if you believe that it is wrong to have sweatshops or whatever it is.' This was a recurring notion often linked specifically to US consumers, who were described by a Kanwi employee as always just looking for the best deal. Therefore, creating a consumer demand for the antitrafficking goods required the conversion of what were considered self-centred, unethical consumers to altruistic, ethical consumers. This involved what Carrie called the 'educational aspect' of Kanwi's work, which involved teaching consumers about the effects of their consumption in the entire supply chain. However, the ethicalisation of consumers involved more than providing information about supply chains. When asked to describe an ethical consumer, the employees emphasised notions of care and awareness. The graphic designer, Lisa, described an ethical consumer as: 'Anyone who can hear our stories and cares, like they just care about others outside of themselves and maybe someone they have never seen before, they might not ever meet, but they relate to that person in some way.... There are people who care and people who are like "aw I am not interested in like helping others".' Thus, the conversion of consumers involved a movement from rational and indifferent ones to those with educated, caring and altruistic concerns.

Kanwi sought to facilitate this movement by articulating consumption as both the cause of and solution to trafficking. Erin, the co-founder, expressed this link by stating that: 'Trafficking thrives on the demand for cheap products. When we look at the demand side [of trafficking], we have to talk about globalisation. Consumers are demanding cheaper products.' Conversely, Lisa described consumers as the most crucial link to solving global issues such as human trafficking: 'Consumerism is so huge, I think we have the power to keep a business going and to shut it down, so it is all up to the consumer.' These links between consumption and trafficking draw on familiar connections made between consumption, labour exploitation and slavery in antisweat shop movements. The links support the argument that the growth of ethical consumption is contingent 
on a discursive production of certain 'moral risks' in consumption. ${ }^{44}$ Thus, Kanwi sought to engage consumers in anti-trafficking by emphasising both the moral risks and possibilities of consumption. In this logic, consumers had two options. By practising what was associated with traditional consumption (such as buying the cheapest option), one could be a potential driver of human trafficking and thus an unethical consumer. By contrast, when shopping in accordance with 'ethical' standards (exhibiting awareness, compassion and altruism), one could be an ally in the fight against trafficking and thus an ethical consumer. This dichotomy shows how life after anti-trafficking emerges as a discursive definition of good and bad consumers, which leaves room for new consumer identities and practices, as I discuss in the following section.

\section{Consuming Life after Anti-Trafficking}

During an interview with Laura, a 35-year old woman living in New York City who had purchased several Kanwi products, she stated that she thought of herself as an ethical consumer all of the time unless she "was cheating'. When asked what she meant by cheating, she explained: 'I usually do not buy Driscoll's [US company that sells fresh berries] and usually I will just forego raspberries if there is not another option, but then one time I was making a cake, I needed raspberries, so I just chose to do it anyway...then I feel like "ugh I am not really being an ethical consumer at this point"'.

The indication that being an ethical consumer involves the occasional 'cheating', i.e. choosing an 'unethical' product (and subsequently feeling guilty about it), was supported by other consumers who expressed that since being an ethical consumer required extensive research on every purchase, the completely ethical consumer 'is a philosophy'. Thus, the ideal of an ethical consumer is perceived as abstract and unattainable. These views support the argument that ethical consumption has become a highly mutable vessel for diverse interpretations of 'doing good', ${ }^{45}$ in effect making everyday acts like buying raspberries a choice between being a good or bad consumer, and indeed a good or bad citizen. ${ }^{46}$ However, this choice was even further complicated by the growing complexity of shopping ethically in a market where corporations can be both ethical and unethical at the same time. For example, Laura shared her ambivalence about supporting Native American protesters in North Dakota with supplies through an Amazon fundraising 'wish list' coordinated by activists and protesters, ${ }^{47}$ because Amazon at the time was affiliated with President Trump's businesses, of which she was a strong opponent. Consequently, Laura was forced to prioritise her ethical concerns since either one would compromise the other. Thus, consumers face a landscape of ethical consumption in which they must navigate between conflicting and ambiguous ethical causes and choose not only if but who to save and support through ethical purchases. ${ }^{48}$

In this complex field of ethical consumption, purchasing anti-trafficking products was presented as an easy choice to make, which consumers rarely questioned. Nearly all consumers uncritically accepted that purchasing a Kanwi handbag was an active step towards ending human trafficking and thus an ethical purchase. This perception, I argue, relied on two related and overlapping discourses. First, Kanwi's emphasis on sexual exploitation rather than other forms of labour exploitation caters to the moral panics about female sexuality mentioned in previous sections and supports the notion that sexual labour is always forced. In Kanwi's annual report, the story of Maya, a woman in Kanwi's programme, describes her new life as being 'free from the bondage of prostitution', which illustrates the equation of sexual labour with captivity and coercion. This conflation in turn supports the framing of commodity production as the equivalent to freedom. For example,

44 C Barnett, P Clove, N Clarke and A Malpass, Globalizing Responsibility: The political rationalities of ethical consumption, WileyBlackwell, West Sussex, 2011, p. 108.

45 See, for example, Vramo, p. 96, for a discussion of how consumers add individual ideas of 'being good' to their ethical purchases, which then become 'vehicles that can take us to who we want to be'.

46 Literature on citizen-consumers describes how citizenship is increasingly expressed through consumption practices. For a brief review, see: R Mukherjee and S Banet-Weiser, Commodity Activism: Cultural resistance in neoliberal times, New York University Press, New York, 2012, p. 5.

47 The Amazon wish list let supporters of the Native American protesters see what items and supplies were needed (such as clean water, shelters and tools) and allowed a coordinated shipment and distribution of support items, https://www.amazon.com/gp/registry/wishlist/18FR1AGDPWZLC.

48 See also: A Major, "Not Made By Slaves": The ambivalent origins of ethical consumption', openDemocracy, 30 April 2015, retrieved 28 December 2017, https://www.opendemocracy.net/beyondslavery/andrea-major/\%27not-made-byslaves $\% 27$-ambivalent-origins-of-ethical-consumption. 
the New York Times journalist Nicholas Kristof has strongly emphasised the freedom and power that wage labour in garment production provides as opposed to sex work, ${ }^{49}$ which contrasts the common denunciation of low-wage factory work. This statement reveals the peculiarity of combining anti-trafficking efforts with ethical consumption, as ethical consumption movements have traditionally protested against women having to work in these sectors in the first place. ${ }^{50}$ However, compared to sex work, the production of consumer goods comes to be perceived as free (i.e. of own free will) labour supported by a Western vision of freedom as the participation in and expansion of a capitalist consumption market. ${ }^{51}$ This representation reproduces discourses of differentiation in which stereotypical notions of victimised women from the Global South in turn define and reassert Western consumers as free and empowered. ${ }^{52}$ Thus, many consumers concluded that only now-in life after anti-trafficking - were the women business women. A female consumer at a Kanwi sales event explained to her boyfriend: 'This is made by women who were rescued from human trafficking, and now they do this instead, and all the profits go right back to them. Now they are business women!' Thus, when engaging in sex work the women were characterised as victims, whereas engaging in low wage production labour cast them as empowered business women.

The second discourse informing consumers' perception of Kanwi products as ethical is the re-branding of trafficking as modern-day slavery. The reliance on slavery rhetoric has been criticised for de-politicising the issue and overlooking the economic and political structures permitting the exploitation of people. ${ }^{53}$ Similarly, when better consumption choices are framed as solutions to slavery, the political structures of global labour exploitation, often reproduced by the same companies that engage in market-based anti-trafficking campaigns, are overlooked..$^{54}$ Thus, conflating trafficking with slavery simplifies both the problem and the solution, such that purchasing a Kanwi product is perceived to be an active fight against human trafficking. Additionally, notions of slavery invoke powerful moral responses and have remarkable popular appeal as an issue that we can all agree is serious and must be condemned. ${ }^{55}$ Consequently, by labelling Kanwi products slave-free, they are presented as unquestionably ethical products from which consumers, when faced with the multiple dilemmas of being an ethical consumer, might find solace. By purchasing Kanwi products, consumers were able to identify as ethical consumers engaging in the indisputably ethical cause of fighting slavery. In this way, life after anti-trafficking emerges among Western consumers not merely as a consumable product, but also as a site of production for new ethical consumer identities.

\section{Conclusion}

I introduced this article with the argument that through the emergence of transnational, market-based antitrafficking organisations, life after anti-trafficking increasingly plays out in sites removed from the trafficking victims. That is, when anti-trafficking efforts rely on the sale of commodities to create new livelihoods for victims, life after anti-trafficking becomes a consumable product and a business opportunity among corporations and consumers in the US. Consequently, anti-trafficking efforts intersect with contemporary consumer movements and political developments of global corporate governance.

Through ethnographic examination of a market-based anti-trafficking organisation, this article has discussed the movement in anti-trafficking efforts from a humanitarian focus on rescue to an emphasis on rehabilitation inspired by market-led development strategies. Practically, this movement involves the presentation of antitrafficking as a business opportunity and a good investment in order to engage corporations in the fight against trafficking. Rhetorically, the movement relies on Western capitalist discourses of freedom as economic independence, the investability of female human capital and entrance into the capitalist labour market as the

49 N D Kristof, 'Inviting All Democrats', New York Times, 14 January 2004, retrieved 15 July 2017 , http://www.nytimes.com/2004/01/14/opinion/inviting-all-democrats.html?mcubz=3.

50 Bernstein, 'Sexual Politics', p. 141.

51 Bernstein, 'Militarized Humanitarianism', p. 64.

52 Fukushima and Hua, p. 47.

53 J A Chuang, "The Challenges and Perils of Reframing Trafficking as "Modern-Day Slavery", Anti Trafficking Review, issue 5, 2015; J O'Connell Davidson, 'New slavery, Old Binaries: Human trafficking and the borders of "freedom", Global Networks, vol. 10, issue 2, 2010.

54 Bernstein, 'Redemptive Capitalism'; Fukushima and Hua, p. 60.

55 B Anderson, Troubling Trafficking: Why I am worried about motherbood and apple pie but don't endorse slavery, DIIS Brief, Danish Institute for International Studies, 2007. 
DOI: $10.14197 /$ atr.201218102

most sustainable route to empowerment. However, as this article points out, these discourses, through which the representation of life after anti-trafficking is sold, do not necessarily reflect the actual life after antitrafficking, since merely advancing production skills does not guarantee economic stability or empowerment. Rather, these representations sustain new market-based ways of doing anti-trafficking work and profitable business opportunities not merely (if indeed at all) for the trafficking victims.

Despite presenting a market-based approach as more sustainable than humanitarian aid, Kanwi was required to spend most of their time creating a consumer demand for the commodities, which relied on creating ethical anti-trafficking consumers. By articulating notions of harmful consumption, consumer responsibility and individual consumer power in relation to trafficking, Kanwi sought to convert 'unethical' consumers to conscious, caring and altruistic consumers. This shows how representations of life after anti-trafficking are translated in a consumer setting to a definition of good and bad consumers, which leaves room for consumers to form new identities through their shopping habits. In a complex and elusive landscape of ethical consumption, in which purchases can be both ethical and unethical and define consumers as either good or bad citizens, the anti-trafficking commodities sold by Kanwi proved ideal for the purpose. Supported by rhetorics of slavery and discursive distinctions between sex work as forced and low-wage production labour as free, the Kanwi product was perceived as an unquestionably ethical purchase. Thus, life after anti-trafficking emerges as a site for consumers to form empowered, ethical and humanitarian identities in which they become bearers of increasing humanitarian responsibilities.

Studying how life after anti-trafficking unfolds in corporate and consumer settings elucidates how the emergence and success of market-based anti-trafficking programmes is bound up with capitalist discourses of freedom and empowerment, politics of global corporate governance and changing moralities and responsibilities within consumption practices. This context thereby permits a broader understanding of how moral and political economies not directly linked to trafficking inform and buttress contemporary antitrafficking interventions and thus affect lives after anti-trafficking. As the actual conditions for victims of trafficking are increasingly contingent upon the participation of consumers in life after anti-trafficking, this emerging circuit of commerce becomes a crucial site to examine.

Sofie Henriksen is a social anthropologist working within the research fields of trafficking, migration, sex work, and the contemporary merges of humanitarianism and capitalism. She holds an M.Sc. in Anthropology from the University of Copenhagen, with a specialised focus on political and economic anthropology. She recently completed her M.Sc. thesis on the intersections of aid and trade in contemporary anti-trafficking campaigns, based on ethnographic fieldwork in New York City. Email: sofie.e.hen@gmail.com 